\title{
Microbiological Quality Assessment of Pupuru and Plantain Flours in an Urban Market in Akure, Ondo State, South Western Nigeria
}

\author{
Christiana Eleojo Aruwa, Omolola Ogundare \\ Department of Microbiology, Federal University of Technology, Akure, Nigeria \\ Email: queen.eleojo29@gmail.com
}

How to cite this paper: Aruwa, C.E. and Ogundare, O. (2017) Microbiological Quality Assessment of Pupuru and Plantain Flours in an Urban Market in Akure, Ondo State, South Western Nigeria. Open Access Library Journal, 4: e3783.

https://doi.org/10.4236/oalib.1103783

Received: June 28, 2017

Accepted: July 31, 2017

Published: August 3, 2017

Copyright ( 2017 by authors and Open Access Library Inc.

This work is licensed under the Creative Commons Attribution International License (CC BY 4.0).

http://creativecommons.org/licenses/by/4.0/

\begin{abstract}
Cassava and plantain flours are commonly used in preparation of a variety of food delicacies in South Western Nigeria. These are however sold in open air markets, and are scarcely required to be subjected to safety checks by food safety authorities. A study was designed to assess the microbiological food quality of cassava (pupuru) and plantain flour purchased from different vendors at Oja-Oba, Akure, Ondo state, as well as the antimicrobial profile of microorganisms identified. Microbiological analyses of sixty (60) food samples were carried out. Results showed highest bacterial counts in plantain flour sample F4 $\left(3.0 \times 10^{4} \mathrm{cfu} / \mathrm{ml}\right)$ and least for F1 $\left(0.1 \times 10^{4} \mathrm{cfu} / \mathrm{ml}\right)$. Fungal count was highest $\left(3.1 \times 10^{4} \mathrm{sfu} / \mathrm{ml}\right)$ in plantain flour F4; and least in plantain flour samples F5, F10, F12 with fungal count of $0.5 \times 10^{2} \mathrm{sfu} / \mathrm{ml}$ each. Different samples contained Enterobacter sp., Aeromonas sp., Klebsiella sp., Acinetobacter sp., Campylobacter sp., Corynebacterium sp. and Bacillus subtilis. Fungal isolates include Penicillium crustosum and P. chrysogenum, Rhizopus oryzae and Aspergillus niger. Percentage occurrence of isolates includes Enterobacter sp. (0.99\%), Klebsiella sp. (91.12\%), Acinetobacter sp. (1.97\%), Campylobacter sp. (4.61\%), Corynebacterium sp. (0.33\%), and Bacillus subtilis (0.99\%). Most predominant mould was Aspergillus niger, with a percentage occurrence of $45.5 \%$; and least, Penicillium crustosum (4.5\%). Gram positive bacteria showed resistance to cotrimoxazole and ceftriaxone; and Gram negative bacteria to zimnacef. The microbial isolates from these flours could cause different food intoxication and illnesses in humans. While prevailing unfavorable environmental conditions and food form may contribute to their presence in samples; their presence is unacceptable and counts need to be kept minimal for consumer safety. Local authorities need to carry out continued vendor education campaigns, and regular quality checks to assess their safety for consumption.
\end{abstract}




\section{Subject Areas}

Microbiology

\section{Keywords}

Pupuru, Plantain, Flour, Food Quality, Antimicrobial, Nigeria

\section{Introduction}

Microorganisms are microscopically small forms of life mainly organised as single-cell organisms while some may occur multicellular. They ubiquitous in the natural environment (water, soil, air etc.), and can naturally be found in foods or on the surfaces of foods as contaminants during the manufacturing process of food products [1]. Food fermentation is the process for producing ATP using endogenous organic compounds as both electron donors and acceptors. The chemical process of fermentation makes a few ATP molecules in the absence of aerobic respiration [2]. Cassava flour (pupuru) is a fermented cassava meal that is consumed by at least $4-6$ million people in Nigeria [3]. Plantain flour is the product of dried and pulverised plantain slices. Plantain is a major source of food in many regions throughout Nigeria and sub-Saharan African. Plantain production reaches over 80 million tonnes per year [4]. Plantain flour apart from being used as a substitute for garri especially for diabetic patient, also serves as raw material used in the production of cakes, puff-puff, biscuit, bread and pancakes. Plantain flour is a cheap source of iron, protein, vitamin C (3.0\% to 3.5\%), and carotene. It could be used in formulating protein supplement diets for both children and adults. The low level of sodium in plantain also makes it a ready source of raw material for formulating low sodium diets [4]. Traditional carbohydrate food such as cassava flour (pupuru) plays a key role in African diet. However, the production processes and sale condition leaves much to be desired as these flours are prone to microbial contamination which may cause food borne illnesses [5].

Food borne illnesses result from consumption of pathogenic bacteria, viruses or parasites that contaminate food, as well as chemical or natural toxins such as those in poisonous mushrooms. The consumption of toxins or microorganisms may cause food poisonings (intoxications) or infections. Contaminating microorganisms enter foods from a variety of sources. Crops carry soil borne bacterial species to the processing plant, and rodents and arthropods transport microorganisms on their feet and body parts as they move about among foods. Human handling of foods also provides a source of contamination. Factors that determine if spoilage will occur include water activity/moisture content of the food stuff, $\mathrm{pH}$, physical structure of the food, presence/absence of oxygen, temperature of storage, food chemical composition [6]. More than 250 different food 
borne diseases have been described [7]. Center for Disease Control and Prevention (CDC) estimated that 9.4 million of the illnesses caused by 31 known food borne pathogens, and that $90 \%$ of all illnesses due to known pathogen are caused by seven pathogens: Salmonella, Norovirus, Campylobacter, Toxoplasma, E. coli 0157:H7, Listeria and Clostridium perfringens [7]. All food borne diseases are associated with poor hygiene practices whether by water or food transmission or through faecal-oral route [8]. Often spoilage microorganisms are introduced from the same source as the food; others are introduced as contaminants during transport, storage or preparation. While observable changes to foodstuff are only likely after the microbial population has reached a considerable size, food poisoning can result from the presence of much smaller number of contaminants [9].

Locally, rural women process cassava into pupuru by steeping peeled cassava tubers in stream water and fermenting it for $4-6$ days. This method of processing fouls the water and increases the level of microbial contaminants in the fermented cassava product [10]. The control and monitoring of conditions in the traditional processing methods are difficult. Another major constraint in the traditional processing of pupuru is the unduly time, as a result of ineffective heat transfer mechanism using the traditional dryer and probably due to the irregular and large sizes of the ball dried. Therefore, proper drying is not achieved and dried balls have the high moisture content, thus the product is susceptible to mold attack as well as developing some off flavor on storage. Also, prolonged drying may institute some changes that could negatively affect some functional properties of the product [11]. Presently in Ondo state of Nigeria, "pupuru" flour is often packaged in polyvinyl chloride container (covered plastic) and stored at ambient temperature $\left(30^{\circ} \mathrm{C} \pm 3^{\circ} \mathrm{C}\right)$. This packaging material does not protect the "pupuru" flour properly from contamination by insect, pests, microbes, dust and environmental moisture [12]. During the entire sequence of food handling, from the producer to the final consumer, microorganisms can affect food quality and human health. Contamination by disease-causing microorganisms can occur at any point in the food-handling sequence [13] [14]. Sources of microorganisms in food include food utensils, food handlers and animal hides [15].

Food borne illness is an international health problem that is common in most developing countries like Nigeria and has led to the death of thousands especially children with low immunity [7]. Screening for microorganisms in pupuru and plantain flour was undertaken to identify possible pathogens and contaminants, determine microbial load and antimicrobial susceptibility pattern of the microbial isolates. Information provided would increase our knowledge of the microorganisms associated with these foods and help in the development of appropriate management protocols to prevent and control associated food borne diseases. Reasons would also be suggested for the comparative distribution of the isolated microbes in the different food samples. 


\section{Materials and Methods}

\subsection{Samples Collection}

A total of sixty food samples (thirty pupuru and thirty plantain flour) purchased from traders in Oja-Oba, Akure Ondo State were used for the study. The samples were collected in sterile polythene bags and transported to the laboratory for microbial analysis [16].

\subsection{Sample Analysis for Microbial Isolation}

Using the pour plate method of Aruwa and Akinyosoye [16], the microbial quality of the food sample was determined. About $1 \mathrm{~g}$ of each food sample was weighed aseptically into test tubes containing $9 \mathrm{ml}$ of sterilized distilled water. Afterwards, the test tubes were shaken vigorously to allow dislodgement of food sample and even distribution of microorganisms. A four-fold serial dilution of each sample was prepared. $1 \mathrm{ml}$ of dilution factor $10^{-2}$ and $10^{-4}$ were inoculated into sterile Petri dishes containing nutrient agar (NA) and potato dextrose agar (PDA) for bacterial and fungal isolation/growth respectively. Incubation was carried out at $37^{\circ} \mathrm{C}$ for 24 hours for bacterial growth, and $25^{\circ} \mathrm{C}$ for $48-72 \mathrm{hrs}$ for fungal growth.

\subsection{Enumeration and Purification of Microbial Isolates}

Colonies were counted at end of incubation period to obtain the total viable count. Calculation of colony forming unit (cfu) per $\mathrm{ml}$ for the bacteria and the spore forming unit (sfu) per $\mathrm{ml}$ for the fungi was done. Distinct colonies were sub-cultured from countable plates using the four-quadrant streak method to obtain pure bacterial cultures. The pure cultures of the bacteria isolated were each maintained in nutrient agar slants and refrigerated at $4^{\circ} \mathrm{C}$. Fungal isolates were purified by the transfer of fungal mycelia plug onto sterile freshly prepared PDA plates. Pure cultures of the fungi isolated were maintained on PDA slants in McCartney bottles and kept in the refrigerator at $4^{\circ} \mathrm{C}[17]$.

\subsection{Identification of Bacterial and Fungal Isolates}

This was carried out according to the method of Cheesbrough [18] and Leboffe and Pierce [19] [20] [21] [22]. Gram's staining was carried out to ascertain the morphology and Gram's reaction of the isolates. Other biochemical tests carried out include catalase, coagulase, urease, spore staining and sugar fermentation. Fungal isolates were identified using microscopic and macroscopic mycelial morphologies.

\subsection{Antibiotics Susceptibility Assay}

In order to determine the susceptibility profile of isolates to clinically relevant antibiotics, the plate diffusion technique of Willey et al. [23] was employed. 18 24-hour old cultures of the isolated bacterial microorganisms were swabbed on sterile, solidified Muller Hilton agar (MHA) plates using sterile swab sticks. The 
multiple antibiotic discs were then placed on the agar surface and pressed using sterile forceps to ensure complete contact with agar. All the plates were incubated at $37^{\circ} \mathrm{C}$ to $24 \mathrm{hrs}$. The zone of inhibition was measured at the point which an obvious demarcation between growth and no growth could be seen using a meter rule. The antibiotics used and their corresponding concentrations were pefloxacin $(10 \mu \mathrm{g})$, chloramphenicol $(30 \mu \mathrm{g})$, gentamycin $(10 \mu \mathrm{g})$, ampiclox (30 $\mu \mathrm{g})$, zimnacef $(20 \mu \mathrm{g})$, amoxacillin $(30 \mu \mathrm{g})$, ciprofloxacin $(10 \mu \mathrm{g})$, streptomycin $(30 \mu \mathrm{g})$, septrin $(30 \mu \mathrm{g})$, erythromycin $(10 \mu \mathrm{g})$, rocephin $(25 \mu \mathrm{g})$, cotrimoxazole $(25 \mu \mathrm{g})$ for Gram positive bacteria; and streptomycin $(30 \mu \mathrm{g})$, chloramphenicol $(30 \mu \mathrm{g})$, gentamycin $(10 \mu \mathrm{g})$, cotrimoxazole $(25 \mu \mathrm{g})$, ofloxacin $(5 \mu \mathrm{g})$, amoxicillin $(25 \mu \mathrm{g})$, ciprofloxacin $(10 \mu \mathrm{g})$, erythromycin $(5 \mu \mathrm{g})$, pefloxacin $(5 \mu \mathrm{g})$ and ceftriazone $(30 \mu \mathrm{g})$ for Gram negative bacteria.

\subsection{Statistical Analysis}

Descriptive analyses were done with prevalence statistics expressed as percentages; and one-way ANOVA (SPSS version 15) for separation of means and determination of significant relationships with the $\mathrm{p}$ set at 0.05 significance level [16].

\section{Results}

The total bacteria count and total fungi count from food samples analysed was presented in Table 1. Highest bacterial count was found in plantain flour sample F4 with $3.0 \times 10^{4} \mathrm{cfu} / \mathrm{ml}$, and lowest in F1 with $0.1 \times 10^{4} \mathrm{cfu} / \mathrm{ml}$. The total fungi count was highest $\left(3.1 \times 10^{4} \mathrm{sfu} / \mathrm{ml}\right)$ in plantain flour $\mathrm{F} 4$ while the least count was observed in plantain flour F5, F10, and F12 with fungal count of $0.5 \times 10^{2}$ $\mathrm{sfu} / \mathrm{ml}$. The identities of the bacteria isolated after colonial morphology, direct microscopic examination using Gram stain, and biochemical tests is presented in Table 2. The bacteria identified include Enterobacter sp., Aeromonas sp., Klebsiella sp., Acinetobacter sp., Campylobacter sp., Corynebacterium sp. and Bacillus sp. The fungi identified include Penicillium sp., Rhizopus sp., Aspergillus sp. (Table 3).

Klebsiella sp. bacterium was the most prevalent in both pupuru and plantain flour with a percentage prevalence of $72.9 \%$ and $94.5 \%$ (Table 4) respectively. The least prevalent among the bacteria isolated were Enterobacter sp. with prevalence of $6.3 \%$ in pupuru and Campylobacter sp. with $5.1 \%$ prevalence in plantain flour. Penicillium crustosum fungus was the most prevalent (66.7\%), while Penicillium chrysogenum was the least prevalent (11.1\%) in pupuru (Table 5). In plantain flour, Aspergillus niger was the most prevalent (61.5\%) and the least prevalence was Rhizopus oryzae with prevalence of $38.5 \%$.

Inhibition zones for Gram negative and Gram positive bacteria were presented in Table 6 and Table 7 respectively. Zones of inhibition for different antibiotics against Gram negative bacteria ranged from $11-29 \mathrm{~mm}$, with the least zone of inhibition recorded for ciprofloxacin against Klebsiella sp. $(11 \mathrm{~mm})$ and 
Table 1. Mean bacterial and fungal count in pupuru and plantain flour samples.

\begin{tabular}{cccccc}
\hline $\begin{array}{c}\text { Pupuru } \\
\text { flour } \\
\text { samples }\end{array}$ & Bacterial count (cfu/ml) & $\begin{array}{c}\text { Fungal count } \\
(\mathrm{sfu} / \mathrm{ml})\end{array}$ & $\begin{array}{c}\text { Plantain } \\
\text { flour } \\
\text { samples }\end{array}$ & $\begin{array}{c}\text { Bacterial } \\
\text { count } \\
(\mathrm{cfu} / \mathrm{ml})\end{array}$ & $\begin{array}{c}\text { Fungal } \\
\text { count } \\
(\mathrm{sfu} / \mathrm{ml})\end{array}$ \\
\hline P1 & $1.1 \times 10^{4}$ & $2.5 \times 10^{4}$ & F1 & $0.1 \times 10^{4}$ & $0.5 \times 10^{4}$ \\
P2 & $1.1 \times 10^{4}$ & 0 & F2 & 0 & $5.5 \times 10^{2}$ \\
P3 & 0 & $0.5 \times 10^{4}$ & F3 & $1.9 \times 10^{4}$ & $1.0 \times 10^{2}$ \\
P4 & $1.1 \times 10^{4}$ & $4.0 \times 10^{4}$ & F4 & $3.0 \times 10^{4}$ & $3.1 \times 10^{4}$ \\
P5 & $0.1 \times 10^{4}$ & $1.0 \times 10^{2}$ & F5 & $4.2 \times 10^{4}$ & $0.5 \times 10^{2}$ \\
P6 & $1.5 \times 10^{4}$ & $0.5 \times 10^{4}$ & F6 & $0.5 \times 10^{4}$ & $1.5 \times 10^{4}$ \\
P7 & $0.54 \times 10^{4}$ & $2.0 \times 10^{4}$ & F7 & $1.5 \times 10^{4}$ & 0 \\
P8 & $1.5 \times 10^{4}$ & $2.0 \times 10^{2}$ & F8 & $1.0 \times 10^{4}$ & 0 \\
P9 & $1.5 \times 10^{4}$ & $0.5 \times 10^{4}$ & F9 & $4.5 \times 10^{2}$ & $2.0 \times 10^{4}$ \\
P10 & $2.0 \times 10^{4}$ & $1.0 \times 10^{4}$ & F10 & $3.5 \times 10^{2}$ & $0.5 \times 10^{2}$ \\
P11 & $0.51 \times 10^{4}$ & 0 & F11 & $2.0 \times 10^{4}$ & $0.5 \times 10^{4}$ \\
P12 & 0 & $3.0 \times 10^{2}$ & F12 & $3.7 \times 10^{4}$ & $0.5 \times 10^{2}$ \\
P13 & $6.6 \times 10^{4}$ & $2.0 \times 10^{4}$ & F13 & $3.0 \times 10^{4}$ & $1.5 \times 10^{4}$ \\
P14 & $0.5 \times 10^{4}$ & $1.0 \times 10^{4}$ & F14 & $7.7 \times 10^{4}$ & $0.5 \times 10^{4}$ \\
P15 & $0.5 \times 10^{4}$ & $0.5 \times 10^{4}$ & F15 & $0.5 \times 10^{4}$ & $0.5 \times 10^{5}$ \\
\hline
\end{tabular}

Key: P1-15 = pupuru samples; F1-F15 = plantain flour samples, from different sellers in Oja Oba market.

Table 2. Microscopic and biochemical characteristics of isolated bacteria from flour samples.

\begin{tabular}{|c|c|c|c|c|c|c|}
\hline $\begin{array}{l}\text { Bacteria } \\
\text { Isolate }\end{array}$ & $\mathrm{A} 1$ & A2 & A3 & A4 & A5 & A6 \\
\hline Shape & Rod & Rod & Rod & Rod & Rod & Rod \\
\hline $\begin{array}{c}\text { Gram } \\
\text { reaction }\end{array}$ & -ve & -ve & -ve & -ve & $+\mathrm{ve}$ & $+\mathrm{ve}$ \\
\hline Catalase & + & + & + & + & + & + \\
\hline Coagulase & - & - & - & + & + & - \\
\hline Glucose & ++ & ++ & +++ & - & - & - \\
\hline Lactose & +++ & +++ & +++ & +++ & +++ & +++ \\
\hline Sucrose & +++ & ++ & +++ & +++ & +++ & +++ \\
\hline Maltose & +++ & +++ & +++ & +++ & +++ & +++ \\
\hline Fructose & ++ & ++ & +++ & ++ & +++ & ++ \\
\hline Urease & $\mathrm{Wu}$ & $\mathrm{Wu}$ & $\mathrm{Wu}$ & $\mathrm{Su}$ & - & - \\
\hline Endospore & - & - & - & - & - & + \\
\hline $\begin{array}{c}\text { Probable } \\
\text { bacteria }\end{array}$ & $\begin{array}{c}\text { Enterobacter } \\
\text { sp. }\end{array}$ & $\begin{array}{l}\text { Aeromonas } \\
\text { sp. }\end{array}$ & $\begin{array}{l}\text { Klebsiella } \\
\text { sp. }\end{array}$ & $\begin{array}{c}\text { Campylobacter } \\
\text { sp. }\end{array}$ & $\begin{array}{c}\text { Corynebacterium } \\
\text { sp. }\end{array}$ & $\begin{array}{l}\text { Bacillus } \\
\text { subtilis }\end{array}$ \\
\hline
\end{tabular}

Key: $+=$ Positive, $++=$ acidic, $-=$ Negative, $+++=$ very acidic, $+=$ fairly acidic, $\mathrm{A}(1,2,3,4,5,6)=$ Probable bacteria, $\mathrm{Wu}=$ weak urease, $\mathrm{Su}=$ strong urease. 
Table 3. Morphology of fungi isolated from flour samples

\begin{tabular}{ccc}
\hline Fungal Isolates & Morphological Characteristics & Suspected fungus \\
\hline Isolate A & $\begin{array}{c}\text { Dull green to grey green. Conidiophore end possess } \\
\text { clusters of two or more branches. }\end{array}$ & Penicillium crustosum \\
Isolate B & $\begin{array}{c}\text { Cotton white, became typically grayish to brown on } \\
\text { surface. Rapid growth. }\end{array}$ & Rhizopus oryzae \\
Isolate C & It is cotton-like in texture. Began as white but later & Penicillium chrysogenum \\
& turned green. & Aspergillus \\
Isolate D & $\begin{array}{c}\text { Black, umbrella-like mycelium shape. No conidia, the } \\
\text { conidiophore hang the spore at the top. }\end{array}$ & niger \\
\hline
\end{tabular}

Table 4. Prevalence of bacterial isolates from pupuru and plantain flours.

\begin{tabular}{ccccc}
\hline Bacteria isolate & $\begin{array}{c}\text { Pupuru } \\
\text { Prevalence }\end{array}$ & $\begin{array}{c}\text { Percentage } \\
(\%)\end{array}$ & $\begin{array}{c}\text { Plantain flour } \\
\text { Prevalence }\end{array}$ & $\begin{array}{c}\text { Percentage } \\
(\%)\end{array}$ \\
\hline Enterobacter sp. & 3 & 6.3 & - & - \\
Klebsiella sp. & 35 & 72.9 & 242 & 94.5 \\
Acinetobacter sp. & 6 & 12.5 & - & - \\
Campylobacter sp. & 1 & 2.1 & 13 & 5.1 \\
Corynebacterium sp. & - & - & - & - \\
Bacillus subtilis & 3 & 6.25 & - & - \\
Total & 48 & 100 & 256 & 100 \\
\hline
\end{tabular}

Table 5. Prevalence of fungal isolates from pupuru and plantain flours.

\begin{tabular}{ccccc}
\hline Fungi isolate & \multicolumn{2}{c}{$\begin{array}{c}\text { Pupuru } \\
\text { Prevalence percentage (\%) }\end{array}$} & $\begin{array}{c}\text { Plantain flour } \\
\text { Prevalence percentage (\%) }\end{array}$ \\
\hline Penicillium crustosum & 6 & 66.7 & - & - \\
Rhizopus oryzae & - & - & 5 & 38.5 \\
Penicillium chrysogenum & 1 & 11.1 & - & - \\
Aspergillus niger & 2 & 22.2 & 8 & 61.5 \\
Total & 9 & 100 & 13 & 100 \\
\hline
\end{tabular}

the higher range recorded for ofloxacin against Enterobacter sp. (29 mm). Zones for Gram positive bacteria, the range was from $7-22.3 \mathrm{~mm}$, with higher range recorded for pefloxacin $(22.3 \mathrm{~mm})$ against Corynebacterium sp., with the least recorded for pefloxacin against Bacillus subtilis $(7 \mathrm{~mm})$.

\section{Discussion}

Changes in microbiological quality of a food item determine its safety, acceptability, shelf stability and its fitness for consumption. The array of microorganisms detected in flour samples used in this study may be associated with contaminated packaging materials, water used during processing, sneezing and coughing by handlers and exposure of flours in an open market environment. Production of most traditional food is often associated with unhygienic prac- 
Table 6. Antibiotics zone of inhibition for Gram negative bacteria.

\begin{tabular}{|c|c|c|c|c|c|c|c|c|c|c|}
\hline \multirow{2}{*}{$\begin{array}{l}\text { Bacteria } \\
\text { isolate }\end{array}$} & \multicolumn{10}{|c|}{ Antibiotic zone of inhibition $(\mathrm{mm})$} \\
\hline & STR & CHL & GEN & $\mathrm{COT}$ & OFL & AMX & CPX & ERY & PFX & CRO \\
\hline $\begin{array}{l}\text { Enterobacter } \\
\text { sp. }\end{array}$ & $17.30 \pm 0.50^{c}$ & $0.00 \pm 0.00^{\mathrm{a}}$ & $0.00 \pm 0.00^{\mathrm{a}}$ & $0.00 \pm 0.00^{\mathrm{a}} 2$ & $29.00 \pm 1.00^{f}$ & $0.00 \pm 0.00^{\mathrm{a}}$ & $25.60 \pm 0.50^{\mathrm{e}}$ & $14.00 \pm 1.00^{\mathrm{b}}$ & $23.00 \pm 0.00^{\mathrm{d}}$ & $0.00 \pm 0.00^{\mathrm{a}}$ \\
\hline Klebsiella sp. & $0.00 \pm 0.00^{\mathrm{a}}$ & $19.00 \pm 1.00^{\mathrm{de}}$ & $17.60 \pm 1.00^{c}$ & $0.00 \pm 0.00^{\mathrm{a}} 1$ & $18.60 \pm 0.50^{\mathrm{cd}}$ & $0.00 \pm 0.00^{\mathrm{a}}$ & $11.00 \pm 0.00^{\mathrm{b}}$ & $17.60 \pm 0.50^{c}$ & $20.00 \pm 1.00^{\mathrm{e}}$ & $0.00 \pm 0.00^{\mathrm{a}}$ \\
\hline $\begin{array}{c}\text { Acinetobacter } \\
\text { sp. }\end{array}$ & $20.00 \pm 1.00^{\mathrm{c}}$ & $21.30 \pm 1.00^{c}$ & $15.00 \pm 1.00^{\mathrm{b}}$ & $0.00 \pm 0.00^{\mathrm{a}} 2$ & $25.00 \pm 1.00^{\mathrm{d}}$ & $14.30 \pm 0.50^{\mathrm{b}}$ & ${ }^{\mathrm{b}} 27.00 \pm 0.00^{\mathrm{e}}$ & $28.00 \pm 1.00^{\mathrm{e}}$ & $16.00 \pm 1.00^{\mathrm{b}}$ & $0.00 \pm 0.00^{\mathrm{a}}$ \\
\hline $\begin{array}{c}\text { Campylobacter } \\
\text { sp. }\end{array}$ & $0.00 \pm 0.00^{\mathrm{a}}$ & $0.00 \pm 0.00^{\mathrm{a}}$ & $0.00 \pm 0.00^{\mathrm{a}}$ & $0.00 \pm 0.00^{\mathrm{a}}$ & $17.60 \pm 0.50^{c}$ & $0.00 \pm 0.00^{\mathrm{a}}$ & $17.30 \pm 0.50^{\mathrm{b}}$ & $0.00 \pm 0.00^{\mathrm{a}}$ & $19.30 \pm 0.50^{\mathrm{d}}$ & $0.00 \pm 0.00^{\mathrm{a}}$ \\
\hline
\end{tabular}

Data are presented as Mean \pm S.E $(n=3)$. Values with the same superscript letter(s) along the same column are not significantly different $(P>0.05)$. Key: $\mathrm{STR}=$ streptomycin $(30 \mu \mathrm{g}), \mathrm{CHL}=$ chloramphenicol $(30 \mu \mathrm{g}), \mathrm{GEN}=$ gentamycin $(10 \mu \mathrm{g}), \mathrm{COT}=$ cotrimozazole $(25 \mu \mathrm{g}), \mathrm{OFL}=\mathrm{oflaxacin}(5 \mu \mathrm{g}), \mathrm{AMX}=$ amoxicillin $(25 \mu \mathrm{g}), \mathrm{CPX}=$ ciprofloxacin $(10 \mu \mathrm{g}), \mathrm{ERY}=$ erythromycin $(5 \mu \mathrm{g}), \mathrm{PFX}=$ pefloxacin $(5 \mu \mathrm{g}), \mathrm{CRO}=$ cetriazone $(30 \mu \mathrm{g})$.

Table 7. Antibiotics zone of inhibition for Gram positive bacteria.

\begin{tabular}{|c|c|c|c|c|c|c|c|c|c|c|}
\hline \multirow[t]{2}{*}{ Bacterial isolate } & \multicolumn{10}{|c|}{ Antibiotic zone of inhibition (mm) } \\
\hline & $\mathrm{AM}$ & $\mathrm{R}$ & CPX & $\mathrm{S}$ & SXT & $\mathrm{E}$ & PEF & $\mathrm{CN}$ & APX & $\mathrm{Z}$ \\
\hline Bacillus subtilis & $0.00 \pm 0.00^{\mathrm{a}}$ & $12.00 \pm 1.00^{\mathrm{d}}$ & $7.00 \pm 1.00^{\mathrm{b}}$ & $12.30 \pm 0.50^{\mathrm{d}}$ & $0.00 \pm 0.00^{\mathrm{a}}$ & $9.6 \pm 0.50^{c}$ & $18.60 \pm 0.50^{\mathrm{e}}$ & $20.30 \pm 0.5^{\mathrm{f}}$ & $0.00 \pm 0.00^{\mathrm{a}}$ & $0.00 \pm 0.00^{\mathrm{a}}$ \\
\hline
\end{tabular}

Data are presented as Mean \pm S.E $(n=3)$. Values with the same superscript letter(s) along the same column are not significantly different $(\mathrm{P}>0.05)$. Key: $\mathrm{AM}=$ amoxicillin $(25 \mu \mathrm{g}), \mathrm{R}=$ rocephin $(25 \mu \mathrm{g}), \mathrm{CPX}=$ ciprofloxacin $(10 \mu \mathrm{g}), \mathrm{S}=$ streptomycin $(30 \mu \mathrm{g}), \mathrm{SXT}=\mathrm{septrin}(30 \mu \mathrm{g}), \mathrm{E}=\mathrm{erythromycin}(10 \mu \mathrm{g})$, $\mathrm{PEF}=$ pefloxacin $(10 \mu \mathrm{g}), \mathrm{CN}=$ gentamycin $(10 \mu \mathrm{g}), \mathrm{APX}=\operatorname{ampiclox}(30 \mu \mathrm{g}), \mathrm{Z}=$ zimnacef $(20 \mu \mathrm{g})$.

tices. This has been documented for these and other food items by Ohenhen et al. [24], Ogori and Gana [25] and Ojokoh et al. [26]. These food samples contain different bacteria that are opportunistic pathogens. If consumed by individuals with compromised immune systems they can cause several types of food borne diseases. Enterobacter sp., Klebsiella sp., Acinetobacter sp., Campylobacter sp., Corynebacterium sp., and Bacillus subtilis are resident and transient bacteria transferred respectively on hands and associated with poor hygiene practices. The high bacteria counts and high occurrence of Klebsiella sp. and presence of other bacteria in plantain and pupuru flours are indicative of potential public health hazard [25].

Penicillium crustosum, Rhizopus oryzae, Penicillium chrysogenum and Aspergillus nigerfungi which were isolated and identified are common moulds in soil, air and organic matter and are therefore ready contaminants of foods and feeds. Aspergillus sp. and Bacillus sp. are known to be associated with dried food [26]. These moulds are responsible for off flavours and taste in food samples, therefore resulting into food spoilage. Aspergillus spp. and Rhizopus spp. are indigenous to cassava fermentation and indication of public health hazard. A. niger is also known to produce mycotoxins (aflatoxins) [25]. The dominating presence of Aspergillus species on the sampled foods could be due to its rapid sporulation, development and relative adaptability to a wide variety of environmental conditions as compared to other species. It also indicates that unconditioned and unhygienic approaches were used in processing [25]. 
Aflatoxins are still recognized as the most important mycotoxins. They are synthesized by only a few Aspergillus species, of which Aspergillus flavus and Aspergillus niger are the most problematic. Obadina et al. [27] reported the presence of Aspergillus, Rhizopus and Penicillium species in other dried cassava products. Shittu et al. [28] also demonstrated the presence of toxigenic moulds like Aspergillus flavus and Penicillium species, which could constitute a health hazard to consumers and cause pupuru spoilage. Their presence and high counts in the flours sampled could be attributed to favourable environmental condition for their growth. The expression of aflatoxin-related diseases is influenced by factors such as age, nutrition, sex, species and the possibility of concurrent exposure to other toxins [29]. Also in this study, antimicrobial sensitivity test was carried out on microbial isolates and found to be of public health significance, having relatively varied antibiotic resistance profiles. Resistance or susceptibility of microbes to antimicrobial agents are determined by inherent microbial genetic and environmental factors. Some of these factors include kinds of microorganism present, the concentration and nature of the antimicrobial, and length of exposure to the agent etc. The wide antibiotic resistance profile of Campylobacter sp. and Bacillus subtilis is of concern as these microbes can cause food borne illnesses. Hence, the tested antibiotics would not be efficacious in the treatment of food borne diseases that may be caused by these microbes. Microorganisms like these may have acquired or developed the ability to resistance and virulence factors to protect themselves in harsh/dry environments. Such trends constitute significant health problems for the future [30].

\section{Conclusion}

The environment plays a critical role in the transmission of infectious agents to humans, with various materials serving as mechanical vehicles. Microbial contaminants may be transmitted directly through hand to hand contact or indirectly via food or other inanimate objects. The present study has focused on the microbiological quality of pupuru and plantain flour and potential health hazard that may arise from consumption of improperly processed flours. Results contribute to ensuring safe food product delivery to meet the demands of consumers now and in future. In order to ensure quality control; prevention of undue food contamination prior to processing, use of adequate and appropriate food processing techniques to avoid contamination during and after foods processing, quality packaging to keep foods fresh and minimize health risk factors, adequate storage, ideal transportation, and hygienic handling of the finished products cannot be overemphasized.

\section{References}

[1] Aruwa, C.E., Akindusoye, A.J. and. Awala, S.I. (2017). Socio-Demographic Characteristics and Food Hygiene Level Assessment of Food Handlers in Cafeterias around a Federal University in Nigeria. Journal of Scientific Research and Reports, 14, 1-9. https://doi.org/10.9734/JSRR/2017/33273 
[2] Pommerville, J.C. (2007) Alcano's Fundamentals of Microbiology: Food Preservation. 8th Edition, Jones and Bartlett Publishers, Inc., Sudbury, 769.

[3] Daily Independent Newspaper (2016) Pupuru: Local Delicacy from Ondo-Life, Food and Beverages. http://www.dailyindependentnig.com

[4] Foraminifera Research (2012) Plantain Production and Processing in Nigeria. http://www.foramfera.com

[5] Wakil, S.M. and Benjamin, I.B. (2015) Starter Developed Pupuru, a Traditional African Fermented Food from Cassava (Manihot esculenta). International Food Research Journal, 22, 2566.

[6] Pommerville, J.C. (2007) Alcano's Fundamentals of Microbiology: Food Spoilage. 8th Edition, Jones and Bartlett Publishers, Inc., Sudbury, 762-764.

[7] Centre for Disease Control and Prevention (CDC) (2015) Food Borne Germs and Illnesses/Food Safety/CDC. https://www.cdc.gov/foodsafety/foodborne-germs.html

[8] Willey, J.M., Sherwood, I.M. and Woolverton, C.J. (2009) Prescott's Principles of Microbiology: Food Borne Diseases. International Edition, McGraw-Hill Companies, Inc., New York, 816.

[9] Stuart, H. (2005) Essential Microbiology: Microbial Spoilage of Food. John Willey and Sons Ltd., Chichester, 427.

[10] Oyetayo, V.O. (2006) Nutrient and Antinutrient Content of Cassava Steeped in Different Types of Water for Pupuru Production. Research Journal of Microbiology, 1, 423-427.

[11] Famurewa, J.A.V., Oluwamukomi, M.O. and Alaba, J.O. (2013) Effect of Different Drying Method on the Physiochemical Characteristics of Cassava Flour (Pupuru). International Journal of Biological and Chemical Sciences, 7, 333.

[12] Daramola, O.A., Idowu, M.A., Atanda, O.O. and Oguntona, C.R.B. (2010) Effect of Packaging Materials on the Quality of "Pupuru" Flour during Storage. African Journal of Food Science, 4, 259.

[13] Prescott, L.M., Harley, J.P. and Klein, D.A. (2002) Microbiology: Food and Industrial Microbiology. 5th Edition, McGraw-Hill, Boston, 972.

[14] Prescott, L.M., Harley, J.P. and Klein, D.A. (2002) Microbiology: Food and Industrial Microbiology. 5th Edition, McGraw-Hill, Boston, 978-981.

[15] Jay, J.M., Loessner, M.J. and Golden, D.A. (2005) Modern Food Microbiology: Primary Sources of Microorganisms Found in Foods. 7th Edition, Springer Science + Business Media, Inc., New York, 33-36.

[16] Aruwa, C.E. and Akinyosoye, F.A. (2015) Microbiological Assessment of Ready-ToEat Foods (Rtes) for the Presence Bacillus Species. Journal of Advances in Biology \& Biotechnology, 3, 145-152.

[17] Dada, E.O. and Aruwa, C.E. (2016) Asymptomatic Bacteriuria Prevalence among Primary School Children in the Federal University of Technology, Akure, Ondo State, Nigeria. Journal of Applied Life Sciences International, 4, 1-8. https://doi.org/10.9734/JALSI/2016/24730

[18] Cheesbrough, M. (2005) District Laboratory Practice in Tropical Countries. 2nd Edition, Cambridge University Press, New York, 38-39. https://doi.org/10.1017/CBO9780511581304

[19] Leboffe, M.J. and Pierce, B.E. (2011) A Photographic Atlas for the Microbiology Laboratory: Endospore Stain. 4th Edition, Morton Publishing Company, Englewood, 61-63.

[20] Leboffe, M.J. and Pierce, B.E. (2011b) A Photographic Atlas for the Microbiology 
Laboratory: Catalase Test. 4th Edition, Morton Publishing Company, Englewood, 73.

[21] Leboffe, M.J. and Pierce, B.E. (2011) A Photographic Atlas for the Microbiology Laboratory: Catalase Test. 4th Edition, Morton Publishing Company, Englewood, 75 .

[22] Leboffe, M. J, And Pierce, B. E. (2011) A Photographic Atlas for the Microbiology Laboratory: Catalase Test. 4th Edition, Morton Publishing Company, Englewood, 106-107.

[23] Willey, J.M., Sherwood, I.M. and Woolverton, C.J. (2008) Antimicrobial Chemotherapy, Prescott, Harvey and Klein's Microbiology. 7th Edition, 835-858.

[24] Ohenhen, R.E., Enweani, I.B., Ogiehor, S.I. and Uwabor, K. (2006) Microorganisms Associated with Preparation of Plantain Pudding in Western Nigeria. African Journal of Biotechnology, 5, 2077-2080.

[25] Ogori, A.F. and Gana, J. (2013) Microbiological Loads of Road Side Dried Cassava Flour from Cassava Balls and Chunks. American Open Journal of Agricultural Research, 1, 24-39.

[26] Ojokoh, A.O., Daramola, M.K. and Ochukwa, A.D. (2014) Studies on the Microbiological, Proximate Composition and Anti-Nutritional Content of Fermented Groundnut and Plantain Blends. Pacific Journal of Science and Technology, 15, 251-258.

[27] Obadina, A.O., Oyewole, O.B. and Odusami, A.O. (2009) Microbiological Safety and Quality Assessment of Some Fermented Cassava Products (Lafun, Fufu, Gari). Scientific Research and Essays, 4, 432-435.

[28] Shittu, T.A., Edema, M.O., Dada, O. and Atayese, A.O. (2010) Microorganisms Associated with the Spoilage of Pupuru. Food Control, 21, 203-206.

[29] Adebayo-Tayo, B.C., Onilude, A.A., Ogunjobi, A.A., Gbolade, J.S. and Oladapo, M.O. (2006) Detection of Fungi and Aflatoxin in Shelved Bush Mango Seeds (Irvingia spp.) Stored for Sale in Uyo Eastern Nigeria. Ejeafche, 5, 1569-1574.

[30] Beceiro, A., Tomás, M. and Bou, G. (2012) Antimicrobial Resistance and Virulence: A Beneficial Relationship for the Microbial World? Enfermedades Infecciosas $Y$ Microbiologia Clinica, 30, 492-499.

Open Access Library

Submit or recommend next manuscript to OALib Journal and we will provide best service for you:

- Publication frequency: Monthly

- 9 subject areas of science, technology and medicine

- Fair and rigorous peer-review system

- Fast publication process

- Article promotion in various social networking sites (LinkedIn, Facebook, Twitter, etc.)

- Maximum dissemination of your research work

Submit Your Paper Online: Click Here to Submit

Or Contact service@oalib.com 